\title{
A Case Study of Exploring Viability of Task-based Instruction on College English Teaching in Big-sized Class
}

\author{
Xiangyang Zhang \\ Jiangsu Radio and TV University, China \\ Shu-Chiu Hung (Corresponding author) \\ Ming Chuan University, Taiwan
}

\begin{abstract}
Task-based instruction has received more pedagogic attention since it was proposed in 1980s. Many studies are found on its characteristics, procedures, and task design. Rather, little research is found to explore its applicability in big-sized classes which averagely are made of more than $\mathbf{5 0}$ students. The present study was undertaken to investigate viability of applying Task-based instruction into big-sized language classrooms. Preand-post written tests, oral tests, and interviews were administered for data collections. Three main findings from the case study are reported: a). the experimental group is likely to have presented significantly better learning attainments while comparing with the control group; b) the experimental group seems to have showed significantly better oral English performance than the control group; c) the experimental group tends to have presented more active and motivated learning than the control group based on data collected from individual interviews. To conclude, the present study has shed light on potentials and practicability of Task-based approach in big-sized classrooms in relation to the participants' learning attainments, oral performance and observed motivated learning motivation in the context of study English as a foreign language (EFL).
\end{abstract}

Index Terms - task-based instruction, big-sized classes, learning attainments, oral performance, observed learning motivation, EFL

\section{INTRODUCTION}

Task-based language teaching and learning (hereafter TBTL) proposed and developed mainly based on research into second language acquisition has received the most pedagogic attention in the field of second/foreign language pedagogy since 1980s. The tenet of TBTL is a pedagogical shift from teacher-oriented to more learner-oriented teaching (East, 2012). Within the context of second/foreign language pedagogy, research foci of TBTL are most devoted to identifying task features and task difficulty, categorizing task types and analyzing task design, interpreting task varieties, and its pedagogic implications (Careless, 2002; Edwards and Willis, 2005; Ellis, 2003; East, 2012; Izadpandah, 2010; Leaver and Willis, 2004; Littlewood, 2004; Nunan, 1989, 2004, 2005; Skehan, 1996, 1998; Van den Branden, 2006; Willis, 1996; Willis and Willis, 2001, 2007). Although benefits/advantages of task-based instruction are substantially supported from a theoretical perspective (East, 2012), yet research evidence supporting to the viability of TBTL remains limited from classroom-based teaching in various pedagogic contexts. That is to say, more classroom-based research is a need to report applicability, viability, and even challenges of implementing TBTL in real teaching practices in any EFL contexts where English is particularly taught and learned as a foreign language (hereafter EFL), and where English language teaching is likely to take place in big-sized language classrooms where, in particular, there are more than 50 students. The paper, therefore, is to report one case study undertaken to explore applicability and practicability of implementing TBTL into College Teaching in big-sized class in the Chinese EFL context in Taiwan.

\section{LITERATURE REVIEW}

The section is to briefly review definitions, components and qualities of tasks, features and paradigm of task-based language teaching and learning, and previous studies on task-based instruction in Taiwan's EFL context.

\section{A. Tasks: Definitions, Components and Qualities}

In research literature, a 'task' denotes various definitions. Long (1985) defines a 'task' to mean any activity in everyday. He writes:

[A task is] a piece of work undertaken for oneself or for others freely or for some reward. Thus, examples of tasks include painting a fence, dressing a child, filling out a form, buying a pair of shoes, making an airline reservation, borrowing a library book, taking a driving test, typing a letter, weighing a patient, sorting letters, taking a hotel 
reservation, writing a cheque, finding a street destination and helping someone across a road. In other words, by 'task' is meant the hundred and one things people do in everyday life, at work, at play, and in between (Long, 1985, p.89 ).

Richard et al. (1986) and Breen (1987) define a 'task' from the perspective of language teaching and learning. They state:

"an activity or action which is carried out as the result of processing or understanding language (i.e. as a response). For example, drawing a map while listening to a tape, listening to an instruction and performing a command, may be referred to as tasks. Tasks usually require the teacher to specify what will be regarded as successful completion of the task. The use of a variety of different kinds of tasks in language teaching is said to make language teaching more communicative ...since it provides a purpose for classroom activities ... since it provides a purpose for a classroom activity which goes beyond the practice of language for its own sake ( Richards, Platt and Weber, 1986, p.289).

“... any structured language learning endeavour which has a particular objective, appropriate content, a specified working procedure, and a range of outcomes for those who undertake the task. 'task' is therefore assumed to refer to a range of workplans which have the overall purpose of facilitating language learning- from the simple and brief exercise type , to more complex and lengthy activities such as group problem-solving or simulations and decision making ( Breen, 1987, p. 23).”

Nunan (1989, p.11) further defines 'the task' in terms of six components. He writes,

"The task is a piece of meaning focused work involving learners in comprehending, producing and /or interaction in the target language, and that tasks are analysed or categorised according to their goal, input data, activities, settings and roles (Nunan, 1989, p.11)."

In line with Nunan (1989), Willis (1996b, p.23) emphasizes that tasks are 'goal-oriented' to achieve an outcome. The main six components of a task are illustrated as below (Nunan, 1989, 2004; Willis, 1996b):

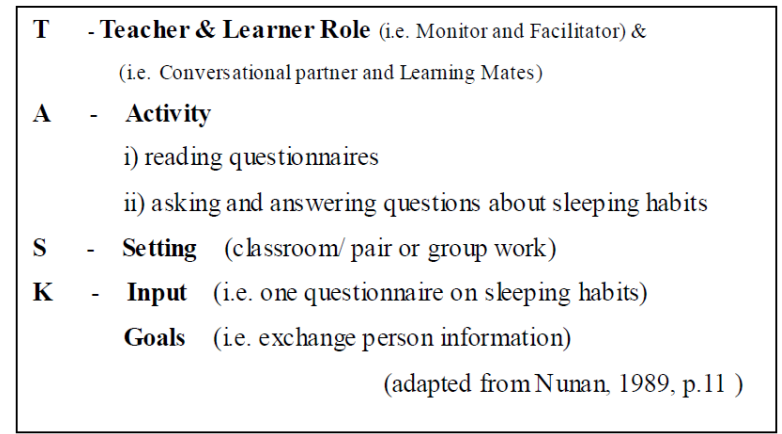

With respect to qualities of tasks, Candlin (1987) provides guidelines for 'good' tasks as follows:

a). Good tasks lead learners to attend to the meaning and to the purposeful language use.

b). Good tasks give learners flexibility in resolving problems on their own ways, and in calling on their own choices of strategies and skills.

c). Good tasks involve learners with their own personalities and attitudes.

d). Good tasks are challenging, yet not excessively demanding.

e). Good tasks raise learners' awareness of the processes of language use, and encourage them to reflect on their own language use.

Willis (1996b, p.36) also suggests that any tasks used in language classroom, should bring following advantages to learners:

a). To develop learners' confidence to try out whatever language they know, or to think what they know in a pair or small group without fear of being wrong or of being corrected in front of the class.

b). To give learners experience of spontaneous interaction, which involves composing what they want to say in real time, formulating phrases and units of meaning, while listening to what is being said.

c). To provide learners a chance to benefit from noticing how others express similar meanings. Research shows that learners are more likely to provide corrective feedback to each other (when encouraged to do so) than adopt each other's errors.

d). To offer all learners chances to practice negotiating turns to speak, initiating as well as responding to questions, and reacting to other's contributions (where in teacher-led interaction, they only have a responding role).

e). To engage learners in using language purposely and co-operatively concentrating on building meanings, not just using language for displaying purposes.

f). To makel learners participate in a complete interaction, not just one-off sentences. Negotiating openings and closings, new stages or changes of direction are their responsibility. It is likely that discourse skills such as these can only be acquired through interaction.

g). To give learners more chances to try out communication strategies like checking understanding, paraphrasing to get round an unknown word, reformulating other people's ideas, and supplying words and phrases for other speakers.

h). To help learners gradually gain confidence as they find they can rely on co-operation with their fellow students to 
achieve the goal of the tasks mainly through the use of the target language.

i). To offer a holistic language experience where learners carry out a communication task, use the language they have learnt from previous lessons or from other sources and gives far more opportunities for free language use and the linguistic content of the language focus phase is far richer.

\section{B. Task-based Language Teaching and Learning: Features and Pedagogic Paradigm}

According to Willis (1996b) and Willis and Willis (2001, 2007), Task-based instruction is identified with following features:

a). A holistic experience of language is provided to learners at the beginning by and then learners are helped to analyze the language they are studying in order to learn more efficiently.

b).The context is already established by the task itself. By the time learners reach the language focus phase, the language is already familiar.

c). Learners raise their consciousness through working on language focus activities which encourage them to think and to analyze.

d). A more varied exposure to natural language is provided through listening and reading.

e). The exposure includes a whole range of words, collocations, lexical phrases and patterns in addition to pre-selected language forms.

f). Learners are free to ask about any aspects of language they notice.

g). The aim is from fluency to accuracy (combined with fluency).

h). All four skills (listening, speaking, reading, and writing) are naturally integrated.

With the respect to the pedagogical paradigm, Task-basked approach can be constructed through a Pre-task $\rightarrow$ Task cycle $\rightarrow$ language focus sequence (Willis, 1996a). The three components are illustrated as follows:

a). Pre-task: an introduction to the topic and the task.

b). Task cycle (task, planning or report): learners hear task recordings or read texts.

c). Language focus (analysis and practice): review and repeat the task.

In contrast, the traditional instruction is constructed through a presentation practice-production sequence as illustrated below:

a). Presentation stage: the stage may consist of pattern sentences given by teachers, or short dialogue illustration target items acted out by teacher, read from textbook, or heard on tape.

b). Practice stage: activities include pattern practice drills, matching parts of sentences, completing sentences or dialogues and asking and answering questions using pre-specified form.

c). Production stage: students are expected to produce language items they have just learnt, together with other previously learnt language. Therefore, in the present study $t$ the experimental group is instructed underpinned by the paradigm of Pre-task $\rightarrow$ Task cycle $\rightarrow$ language focus (Willis, 1996a) whereas the controlled group is instructed mainly based on the presentation- practice-production paradigm.

In the present study, teaching interventions were designed based on the two aforementioned paradigms, and were given to the experimental group and the controlled group respectively for one semester.

\section{Previous Studies on Task-based Instruction in Chinese EFL Context in Taiwan}

Since 2000, research into task-based language teaching and learning (hereafter TBTL) has started, and impacts of its implementation on classroom teaching continue to be examined in EFL contexts. In Taiwan's EFL context, research into applications of Task-based instruction is mainly found in English education at the primary and secondary levels. Fan-Jiang (2005), Tseng (2006), Ho (2006), and Chao (2008) researched TBTL in primary schools, and they reported that their participants' learning motivation and attitudes, English vocabulary, and English speaking were enhanced through TBTL. Lee (2004) and Guo (2006) studied implementing TBTL into English teaching in junior and senior high schools. They also reported that TBTL had positive effects on their students in learning confidence, English reading and English speaking. More importantly, these studies all point out that the use of TBTL in English classroom teaching is quite challenging as English has been learned as one subject of foreign languages in schools in Taiwan. As to research into TBTL at the tertiary level of English language education, Chuang (2010a, 2010b) investigated its implementation into oral English teaching class, and she found positive impacts of TBLT on her participants' oral interactions, communication strategies, learning motivation and attitudes. However, classroom-based research into applications of TBTL remains little in big-sized classroom settings at the tertiary level of English language education in Taiwan. Therefore, the present study aimed to explore the viability of TBTL in big-sized classrooms in relation to learning attainments/outcomes, oral performance, and learning attitudes/motivations.

\section{RESEARCH Methodology}

Research context, research questions, data collections, research participants, and the experimental teaching are briefly described in this section.

\section{A. Research Context and Research Questions}


As TBTL was initiated to teach language in small classes, it is assumed that TBTL may not be applicable in big-sized language classes. In research literature, however, definitions of large classes' vary from context to context (Hayes, 1997; Al-Husseini, 2009). Hayes (1997, p.115) points out that 'there can be no quantitative definition of what constitutes a 'large' class.' A class size is difficult to be defined in terms of large or small. According to Hess (2001, p.1), if a class consists of 30 and more learners, the class can be big-sized. Hayes (1997) points out that in EFL contexts like Thailand, teachers may consider a class which has 45 to 55 students as a large class. In the participating university for the present study, the number of students in each class is approximately 45 to 55 . The class could be regarded as big-sized according to Hayes (1997) and Hess (2001).Therefore, the present study aimed to answer three research questions as follows:

Research Question 1: To what extent may Task-based instruction improve Chinese college students' learning attainments while implementing it into big-sized class teaching?

Research Question 2: What is the impact of Task-based instruction on EFL learner's oral English performance while implementing it into big-sized college English teaching?

Research Question 3: What is the impact of Task-based instruction on Chinese college students' motivation/attitudes while implementing it into big-sized college English teaching?

\section{B. Data Collections}

Written tests, and oral tests were employed and administered for data collections before and after teaching interventions. In addition, ten participants from the experimental group and the controlled group respectively were given 15-20 individual interviews. Interviews were recorded and transcribed for data analysis.

\section{Research Participants and the Teaching Experiment}

The Chinese participants in the case study were 103 freshmen, studying in one university in the northern Taiwan. Among them, 30 students are males, and 73 are females. The average age is 18.5, and the average year of learning English is 10.6.

This study adopted classroom-based experimental research design. One control group received traditional teaching whereas one experimental group received task-based teaching. The teaching treatments were given to the two groups respectively for one semester in an academic year. The experimental teaching was undertaken for one semester, including 16 weeks of teaching, one week of the mid-term examination and one week of the final examination. The teaching was two hours in every week, and the main textbook used in the course was Cover to Cover 2: Reading Comprehension. One class having 52 students was randomly assigned to be the control group, and another class with 51 students as the experimental group. The control group was given teaching treatments based on the presentation-practice-production paradigm. The content of teaching focused more on vocabulary, language knowledge and form practice and production. In contrast, the experimental group was given teaching treatments based on the Pre-task $\rightarrow$ Task cycle $\rightarrow$ language focus paradigm proposed by Willis (1996). Tasks focus more on guiding students to comprehend, act and complete any tasks through working in pairs/ groups (Long and Crookes, 1993, and see Appendix for examples). Types of teaching, paradigms, interaction, the teacher role, the student roles and weeks of teaching involved in the present study are showed as in Table 3.1.

TABLE 3.1:

THE COMPARISON OF THE CONTROLLED GROUP AND THE EXPERIMENTAL GROUP

\begin{tabular}{|l|l|l|}
\hline Group & The Controlled Group $(\mathrm{N}=52)$ & The Experimental Group $(\mathrm{N}=51)$ \\
\hline Teaching Approach & Traditional Teaching & Task-based Approach \\
\hline Teaching Paradigm & Presentation $\rightarrow$ Practice $\rightarrow$ Production & Pre-task $\rightarrow$ Task cycle $\rightarrow$ Language focus \\
\hline Contents of Teaching & Vocabulary and language ,knowledge & Tasks-Learning Activities \\
\hline Teacher Orientation & Teacher-Oriented & Learner-Oriented \\
\hline Interaction & From Teachers to Learners & Learning mates in Pairs/ Groups \\
\hline The Role of Teacher & Knowledge Transmission & A Helper, an Observer \\
\hline The Role of Students & More passive learners & More active learners \\
\hline $\begin{array}{l}\text { Weeks of Teaching } \\
\text { Treatments }\end{array}$ & $\begin{array}{l}16 \text { weeks x 2 hours + 1 week (the mid-term } \\
\text { exam) and 1 week (the final examination). }\end{array}$ & $\begin{array}{l}\text { 16 weeks of teaching + 1 week (the mid-term } \\
\text { exam), and 1 week (the final examination). }\end{array}$ \\
\hline
\end{tabular}

\section{RESULTS AND DiSCUSSION}

The results of the present study are reported with respect to research questions proposed as follows:

Research Question 1:

To what extent may Task-based instruction improve Chinese college students' learning attainments while implementing it into big-sized class teaching?

The data of the participants' written test performance were collected to examine their learning attainments/outcomes. T-Test was operated to compare test grades. Table 4.1 shows the difference in the pre-test and the post-test between the control group and the experimental group. The difference in the pre-test is not statistically significant $(\mathrm{t}=0.864$, $\mathrm{P}=0.39>0.05$ ). That indicates that the controlled group and the experimental group could be regarded as two comparable groups before the teaching treatment. However, after the teaching interventions the difference in the post-test between 
the experimental group and the control is reported to be statistically significant $(\mathrm{t}=2.242, \mathrm{P}=0.02<0.05)$. This finding seems to imply that in the present study Task-based instruction has positive effects on learning attainments while implementing it into big-sized classroom teaching.

TABLE 4.1

DIFFERENCE IN PRE-AND-POST TEST BETWEEN THE CONTROL GROUP AND THE EXPERIMENTAL GROUP

\begin{tabular}{|c|c|c|c|c|c|c|c|c|c|c|}
\hline \multirow[t]{2}{*}{ Test Type } & \multicolumn{5}{|c|}{ Pre-Test } & \multicolumn{5}{|c|}{ Post-Test } \\
\hline & $\mathrm{M}$ & SD & $\mathrm{F}$ & $\mathrm{t}$ & $\mathrm{P}$ & $\mathrm{M}$ & SD & $\mathrm{F}$ & $\mathrm{t}$ & $\mathrm{P}$ \\
\hline $\begin{array}{l}\text { The Experimental } \\
\text { Group } \\
(\mathrm{N}=52)\end{array}$ & 61.63 & 6.74 & 2.246 & 0.864 & 0.39 & 67.07 & 4.38 & 0.743 & 2.242 & 0.02 \\
\hline $\begin{array}{l}\text { The Control } \\
\text { Group } \\
(\mathrm{N}=51)\end{array}$ & 59.65 & 5.09 & & & & 62.36 & 5.99 & & & \\
\hline
\end{tabular}

In addition, Table 4.2 shows the written grades of the two groups before and after teaching interventions.

TABLE 4.2:

WRITTEN TEST GRADES OF THE CONTROL GROUP AND THE EXPERIMENTAL GROUP

\begin{tabular}{|c|c|c|c|c|c|c|c|c|c|c|}
\hline Groups & \multicolumn{5}{|c|}{ The Experimental Group $(\mathrm{N}=52)$} & \multicolumn{5}{|c|}{ The Control Group $\quad(\mathrm{N}=51)$} \\
\hline & $\mathrm{M}$ & SD & $\mathrm{F}$ & $\mathrm{t}$ & $\mathrm{P}$ & $\mathrm{M}$ & SD & $\mathrm{F}$ & $\mathrm{t}$ & $\mathrm{P}$ \\
\hline Pre-Test & 61.63 & 6.74 & 1.21 & -4.51 & 0.01 & 59.65 & 5.09 & 1.56 & -1.681 & 0.10 \\
\hline Post-Test & 67.07 & 4.38 & & & & 62.36 & 5.99 & & & \\
\hline
\end{tabular}

As seen from Table 4.2 above, both the control group and the experimental group showed improvements in learning attainments in the post-test after teaching interventions (the experimental group: the pre-test $\mathrm{M}=61.63$, the post -test $M=67.07$; the controlled group: the pre-test $M=59.65$, the post-test $M=62.36$ ). It is also showed that the difference of the experimental group in the pre-test and the post-test is statistically significant $(\mathrm{t}=-4.51, \mathrm{P}=0.01<0.05)$ whereas the difference of the control group is not statically significant ( $\mathrm{t}=-1.681, \mathrm{P}=0.10>0.05$ ). That is, in the present study Task-based approach is likely to have positive effects on the participants' learning of English whereas compared with the traditional approach.

Research Question 2:

What is the impact of Task-based instruction on EFL learner's oral English performance while implementing it into big-sized college English teaching?

During the process of oral tests, 4 participants in the experimental group, and 4 participants in the control group were absent in the scheduled tests. The 8 participants were, thus, removed from data analysis of oral performance. The two oral tests were rated by two experienced English teachers. The score of each participant is the average score rated by the two raters. The oral scores of the experimental group and the control group are showed as in Table 4.3.

TABLE 4.3:

ORAL SCORES OF THE CONTROLLED GROUP AND THE EXPERIMENTAL GROUP

\begin{tabular}{|c|c|c|c|c|c|c|c|c|c|c|}
\hline & \multicolumn{5}{|c|}{$1^{\text {st }}$ Oral Test } & \multicolumn{5}{|c|}{$2^{\text {nd }}$ Oral Test } \\
\hline & $\mathrm{M}$ & SD & $\mathrm{F}$ & $\mathrm{t}$ & $P$ & $\mathrm{M}$ & SD & $\mathrm{F}$ & $\mathrm{t}$ & $P$ \\
\hline $\begin{array}{l}\text { The Control Group } \\
(\mathrm{N}=47)\end{array}$ & 78.68 & 6.026 & 0.423 & 1.492 & 0.14 & 82.62 & 5.66 & 0.566 & 3.576 & $0 \cdot 01$ \\
\hline $\begin{array}{l}\text { The Experimental } \\
\text { Group } \\
(\mathrm{N}=48)\end{array}$ & 77.27 & 7.64 & & & & 76.55 & 6.82 & & & \\
\hline
\end{tabular}

From Table 4.3 above, it is found that there is only slightly mean difference between the control group and the experimental group in the first oral test (the control group's $M=77.27$; the experimental group's $M=78.68$ ). The difference is not significant as it reads $\mathrm{t}=1.492, \mathrm{p}=0.14>0.05$. In contrast, the experimental group showed better mean scores than the control group in the second oral test; the mean of the experimental group is $\mathrm{M}=82.62$ whereas the controlled group is $M=76.55$. The difference between the experimental group and the control group in the second oral test is reported to be significant as it reads $\mathrm{t}=3.576, \mathrm{p}=0.01<0.05$. This finding is likely to indicate that the implementation of Task-based instruction in the present study could benefit Chinese EFL learners in their oral performance while comparing with the traditional instruction. The finding is consistent with, and supports the results of Chuang's (2010a, 2010b) studies. In addition, the following responses of the participants in the experimental group extracted from individual interviews also support this finding:

'My English speaking is practiced in the classroom, and I am not so afraid of speaking English. (EG 03)'

'I like to do the team-work task with my classmates in English (EG07).'

'I have opportunities to speak out in English in class (EG04).'

'I find English speaking not so difficult as before (EG06).'

'I use English more while talking with classmates in English, and doing the work together with classmates in class (EG02).'

Research Question 3: 
What is the impact of Task-based instruction on Chinese college students' motivation/attitudes while implementing it into big-sized college English teaching?

While compared with the traditional way of instruction, it is likely that Task-based instruction implemented in big-sized classroom teaching in the present study has positive effects on learners' motivation and attitudes. The interviewees from the experimental group have showed their positive responses while being asked to describe their experience of learning in the class. Their responses are as follows:

'I feel the class is different. We have to do lots of tasks with classmates, and have to use English (EG01).'

'Studying English is more interesting than before (EG02).'

'Sometimes, we laughed when our team did work together in class (EG04).'

'To study English can have lots of fun (EG08).'

'I like to know more about English (EG09).

'I like to use English and learn in class (EG10).'

In contrast, the interviewees from the controlled group have showed different responses while being asked to describe their learning experience. Their responses are as follows:

'The English class is a bit dull (CG01).'

'I feel that my English is not improved (CG03).'

'The practice in class is useful, but it is really difficult to study English well (CG06).'

'Lots of classmates do not pay attention in class (CG08).'

'Teachers try to help us to learn, but I do not like to study English. It is very difficult to learn English well (CG10).'

Although the teacher who provided the traditional instruction did her best to provide the control group with a variety of vocabulary and to change ways of doing language practice with the control group, yet it is likely that the participants in the control group seem to be less motivated to study English more, and to initiate more self study of English. The finding of the present study on Task-based instruction is also consistent with the results of many previous studies in Taiwan's EFL setting (Chao, 2008; Chung, 20110a, 2010b; Gao, 2006; Ho, 2006; Lee, 2006; Tseng, 2006).

\section{CONCLUSION}

The paper reported a classroom-based case study undertaken to investigate viability and impacts of implementing Task-based instruction into College English Teaching in big-sized class. The results have showed the potentials of Task-based instruction in big-sized class teaching in three aspects: a) the participants given TBTL are likely to have similar or better learning attainments while comparing with those who were given teaching treatments based on the traditional instruction; b) TBTL in the study has made positive impacts on the participants' oral English performance; c). the participants receiving TBTL teaching treatments are likely to present better learning motivation/attitudes than those who receiving the traditional teaching. The results of the present study are consistent with previous studies on TBTL in Taiwan's EFL context. However, the challenge of implementing TBTL into big-sized class English teaching is also perceived and experienced in the present study in relation to course design and classroom management. In future, more research into TBTL in language teaching in big-sized class should be encouraged to provide more insights into the viability of TBTL in any global EFL contexts.

\section{APPENDIX. SAMPLES OF TASKS USED IN TASK-BASED TEACHING INVENTIONS TO THE EXPERIMENTAL GROUP IN THE PRESENT STUDY}

\section{A). The Information-Gap Task:}

The class is divided into 14 groups, and each group consists of 3-4 students. Each group is assigned one theme to collect data, and to report in class. In class, they also have to offer open questions for discussion, answer questions from the teacher about the textbook reading and other relevant issues. At the end, the teacher and other classmates have to give grades to the group based on their presentation and reports.

B). The Reasoning-Gap Task:

As two themes are about Stereotypes and Korea Soup Operas in the syllabus, the teacher designed writing task for students do 'plot constructions'. The teacher showed a clip from YouTube first, and then paused, and asked students to predict, and to write down what will happen next, and the ending of the story. After students completed their writing, the teacher continued playing the clip to the end. After that, the teacher and students discuss, and compare their prediction, and what happened in the clip.

C) The Opinion-Gap Task:

This is a task for students to practice how to debate in English debates. The teacher prepared playing cards (5 red heart/diamond and 5 black club/spade). The students are divided into 10 groups (5 students in each group). 1-2 students can be judges. The groups picking up the red heart/diamond are the Pro-Group for the topic, and other groups picking up the black club/spade are the Against-Groups. Then, each member in every group has to pick up one playing to decide the order of doing debate. Then, the teacher randomly assigned one pro- group to debate with one against-group. After that, the teacher gave the topics out for 10-minute preparations. At the end, the best Pro-Group, and Against-Group were elected by the teacher and students. 


\section{REFERENCES}

[1] Al-Husseini, S.S. (2009). English language teachers' perceptions of class size and the factors that influence them. Ibra Journal of English Language Teaching May, 2009, 48-65.

[2] Breen, M.P. (1987). Learner contributions to task design. In Candlin, C.N. and Murphy, D.F. (eds.) (1987). Language Learning Tasks. pp.23-46 London: Prentice Hall.

[3] Carless, D. (2002). Implementing task-based learning with young learners. ELT Journal 56(4), 389-396.

[4] Chao, J.C. (2008). A Study of task-based learning and teaching in a large EFL class. Unpublished mater thesis, National Taiwan University of Science and Technology, Taiwan.

[5] Chuang, Y. (2010a). The study of using Task-based instruction in the College EFL classroom. Journal of Chang Rong University 14 (2), 33-48.

[6] Chuang, Y. (2010b). Task-based language approach to teach EFL speaking. Journal of National Hu-Wei University of Technology and Science 29 (4), 37-52.

[7] East, M. (2012). Task-Based Language Teaching from the Teachers' Perspective. Amsterdam: John Benjamins B.V.

[8] Edwards, C. \& Willis, J. (eds.) (2005). Teachers exploring tasks in English language teaching, Houndmills: Palgrave MacMillian.

[9] Ellis, Rod. (2003). Task-based Language Learning and Teaching. Oxford: Oxford University Press.

[10] Fan-Jiang, I.C. (2008). The Effectiveness of implementing task-based instruction in a primary school in Taiwan. Unpublished master thesis, Yuan Ze University, Taiwan.

[11] Guo, J.C. (2006). Implementing a task-based approach with senior high school students: Characteristics of interactions and students' perceptions. Unpublished master thesis, the National Cheng Hwa University, Taiwan.

[12] Hess, N. (2001). Teaching Large Multilevel Classes. Cambridge: Cambridge University Press.

[13] Hayes, D. (1997). Helping Teachers to Cope with Large Classes. ELT Journal 51(2), 106-116.

[14] Ho, T.L. (2006). The Impact of task-based language teaching on word recognition and early reading achievement in elementary school students. Unpublished master thesis, Taipei Educational University, Taiwan.

[15] Izadpandah, S. (2010). A Study on Task-based language teaching: From theory to practice. US-China Foreign Language 8(3), 47-56.

[16] Lee, I. L. (2004). A Study of teachers' and students' perceptions of task-based EFL instruction in vocational high school setting. Unpublished master thesis, the National Chung Cheng University, Taiwan, R.O.C.

[17] Leaver, B. and Willis, J. (Eds.). (2004). Task-based Instruction in foreign language education. Washington: Georgetown University Press.

[18] Littlewood, W. (2004). The task-based approach: Some questions and suggestions ELT Journal 58(4), 319-326.

[19] Long, M. (1985). The role of instruction in second language acquisition: Task-based language teaching. In Hyltenstam, K. and Pienemann, M. (Eds.) 1985 Modelling and Assessing Second Language Acquisition. pp.77-99. San Diego, CA: College-Hill Press.

[20] Long, M. \& Crookes, G. (1993). Units of Analysis in Syllabus Design. In Croolkes, G. and Gass, S. (Eds.), (1993). Tasks in a pedagogical context: Integrating theory and practice. PP.9-54. Clevedon: Multilingual Matters.

[21] Nunan, D. (1989). Designing Tasks for the Communicative Classroom. Cambridge: Cambridge University Press.

[22] Nunan, D. (2004). Task-Based language teaching. Cambridge, UK: Cambridge University Press.

[23] Nunan, D. (2005). Important tasks of English educators: Asian-wide and Beyond. Asian EFL Journal 7 (3), 21-34.

[24] Richards, J., Platt, J. \& Webber, H. (1986). A Dictionary of Applied Linguistics. London: Longman.

[25] Day, R.R. \& Harsch, K. (2008). Cover to Cover: Reading Comprehension and Fluency. Oxford: Oxford University Press.

[26] Skehan, P. (1996). A framework for the implementation of task-based instruction. Applied Linguistics. 17, 38-62.

[27] Skehan, P. (1998). A Cognitive Approach to Language Learning. Oxford: Oxford University Press.

[28] Tseng, C.Y. (2006). A Study of the effect of task-based instruction on primary school EFL students. Unpublished master thesis, the National Chung Cheng University, Taiwan.

[29] Van den Branden, K. (ed.) (2006). Task-based language education: From theory to practice. Cambridge: Cambridge University Press.

[30] Willis, Jane. (1996). A Framework for Task-based Learning. London: Longman.

[31] Willis, D. \& Willis, J. (2001). Task-based learning. In Carter, R. \& Nunan, D. (eds.) The Cambridge Guide to Teaching English to Speakers of Other Languages. Cambridge: Cambridge University Press.

[32] Willis, D. \& Willis, J. (2007). Doing Task-based Teaching. Oxford: Oxford University Press.

Xiangyang Zhang has been a senior visiting fellow at the University of Nottingham, UK. Currently, he is working at the Department of Foreign Language Studies, Jiangsu Radio and TV University, Nanjing. His research interests are English teacher education, learning strategies, learner belief system, and English distance learning, and web-based learning system.

Shu-Chiu Hung has obtained her Ph.D. in Applied Linguistics/English Language Teaching, School of English Studies, the University of Nottingham, UK. Currently, she is working at the Department of Applied English, School of Education and Languages, Ming Chuan University, Taiwan. Her research interests include second language pedagogy, second/foreign language acquisition, and distance learning. 